\title{
Opportunities for improving congress tourism's competitiveness
}

\author{
Miroslava Dimitrova ${ }^{1}$
}

Received: 15/09/2010

\footnotetext{
${ }^{1}$ International University College - Dobrich, Bulgaria, Phone: +35958 655630

e-mail: miroslava.dimitrova@vumk.eu
}

Supervisor: Prof. Tichomir Pelov, Ph.D, University of National and World Economy, Sofia, Bulgaria Institution awarding the Ph. D. Degree: University of National and World Economy, Sofia, Bulgaria Date of defence: $25^{\text {th }}$ March 2010

(C) 2010 International University College. All rights reserved

Citation: Dimitrova, M. (2010) Opportunities for improving congress tourism's competitiveness. Doctoral dissertation summary. European Journal of Tourism Research 3(2), pp. 135-137

\section{Goal and objectives of the dissertation Goal}

The main goal of the dissertation is to elaborate models for analysis and appraisal of congress tourism competitiveness on micro (hotel or congress centre) and macro (congress destination) level and to formulate proposals for its improvement.

\section{Objectives}

1. Presenting a theoretical concept on congress tourism and its competitiveness

2. Designing and implementing a model for analysis and appraisal of congress destination competitiveness

3. Designing and implementing a model for analysis and appraisal of congress hotel / congress centre competitiveness

4. Outlining the opportunities for improvement of the competitiveness of congress tourism on micro and macro level

\section{Methodology}

The research is based on qualitative and quantitative approach. Primary data is obtained through observation, semi-structured interviews with hotel and congress centre managers, as well as representatives of various tourism organisations and associations, site visits and venues inspections. The author's professional expertise in the area enables the collection of significant up-to-date information concerning the congress industry in Bulgaria. Secondary data is obtained through statistics and other informational bulletins, revue of relevant papers, articles and web sites.

The congress tourism product is divided in different elements. Every element and stage of its production is researched. The conclusion presents theoretical and practical implications which are revealed by a number of cross case studies. Methods of deduction and comparative analysis are being used to 
formulate models of appraisal of congress tourism competitiveness.

The main impediment for the research is the lack of reliable statistic data regarding the congress tourism sector in Bulgaria.

\section{Results}

The dissertation proposes models for analysis and appraisal of congress tourism competitiveness on both - mirco (hotel/congress centre) and macro (congress destination) levels based on comparative approach.

The congress facilities including hotels, purpose-built centers, academic and other public venues which exist in Bulgaria are thoroughly researched and catalogued.

A comparative analysis of the eight major tourist regions in Bulgaria has been made. The regions are ranged according to their potential for development of congress tourism, while their competitive advantages and disadvantages have been pinpointed.

Based on the proposed model, an analysis of national competitiveness of Bulgaria as a congress destination has been made.

Opportunities for improvement of national, regional and company competitiveness concerning the congress tourism have been outlined.

\section{Theoretical conclusions}

The dissertation comprises a large volume of literature in the area of congress, conference and business tourism, MICE industry and event management, destination and firm competitiveness. Based on deductive approach the author formulates concepts such as "congress destination" and "congress tourism competitiveness". The theoretical models for analysis and appraisal of congress competitiveness are based on existing models for analysis and appraisal of country, destination and firm competitiveness.

The research confirms that Bulgaria has a high potential to be successfully positioned as a congress destination. The main competitive advantages are the substantial and well- equipped facilities (hotel and congress centres), availability of bilingual and welltrained human capital, high level of technical provisions, abundance of natural and cultural resources. The country is still behind its main competitors regarding the number of specially-designed congress and conference centres, infrastructure (transportation, social, security provision) and scarcity of government support for the sector. The formation of a national congress association involved in creating a destination marketing policy is a must. New educational programmes majoring in event management and congress tourism should be developed and introduced. The country has a significant potential in using academic buildings, public and government halls, museum and other unusual venues as congress tourism facilities

\section{Practical application of the dissertation}

The dissertation could be in a valuable assistance in the process of designing and implementing national and regional marketing destination policy. The individual companies (hotels, purpose-built congress centres and other venues) could apply the proposed models for measuring their competitiveness in comparison to their main rivals which could impact the company strategy and future development.

The dissertation contains the most thorough and up-to-date research on the congress facilities in Bulgaria, sorted by region and category, which makes it a valuable reference tool for event managers, companies and individuals during the process of venue selection. The proposed opportunities and ways of increasing the national, regional and firm competitiveness are feasible and could have a significant impact when applied.

\section{Content of the dissertation}

Abstract of chapter one

The first chapter of the dissertation aims to comprise the relevant terminology, to present main participants on the supply and demand side of the congress markets and to study the development of the congress tourism as well as the scope of the congress industry in present days. The main international and 
national congress organization and their core activities have been outlined. The advantages of the congress tourism compare to mass tourism have been pinpointed. The end of the first chapter refers to the competitiveness of congress tourism, key definitions and methodology for its analysis and appraisal.

\section{Abstract of chapter two}

The second chapter analyze and appraise the competitiveness of congress tourism on two levels: macro (congress destination) and micro (hotel and purpose built congress center). On base of thorough research of the existing methodology, new models for analysis of congress competitiveness have been proposed. These models are used to evaluate the regional competitiveness of eight main tourist destinations in Bulgaria, the overall national competitiveness, as well as the competitiveness of a congress hotel, "Flamingo Grand", situated in Albena resort.

\section{Abstract of chapter three}

The third chapter reveals the opportunities for increasing the congress tourism competitiveness on national, regional and company level, which are as follows:

- Formation of congress marketing organizations on national and regional level

- Formulating a strategy for congress tourism development

- Implementing a marketing policy for congress tourism, including publicity and trade shows attendance

- State investment in building new purposebuilt centers
- Economic incentive for congress tourism development (including tax concessions, subsidies, low-interest government loans for conference tourism projects etc)

- Legislation improvements such as introduction of new objects (congress centers) in Law of Tourism, classification and rating of congress facilities etc.

- Improvement of capacity and structure of congress facilities in Bulgaria by building of new purposed built centers, five and four stars congress hotels and larger use of academic and state buildings as conference venues.

- Improvement of informational database concerning the congress industry by appointing a governmental body in charge of collecting and updating relevant statistics for the sector

- Introduction of new modules in Event and congress management in colleges and universities.

- Improvement in regional infrastructure. The main measurements here are building of small and medium-sized airports near the congress hubs and improvement of roads and railroads condition

On micro (hotel/ congress centre) level the proposed opportunities concern the improvement of quality/price ratio which is evident in the different element of the marketing mix of the congress product. A special attention is given to the relatively new and still evolving concepts of "custom care" and "guest relation" which have primary significance for achieving and sustaining a competitive advantage. 